\title{
Estrogen-like and tissue-selective effects of 7-methoxycoumarin from Ficus umbellata (Moraceae): an in vitro and in vivo study
}

\author{
Stéphane Zingue ${ }^{1,2,3^{*}}$, Thomas Michel ${ }^{4}$, Chantal Beatrice Magne Nde ${ }^{5}$, Amstrong Nang Njuh ${ }^{1}$, Julia Cisilotto ${ }^{2}$,
} Derek Tantoh Ndinteh ${ }^{3}$, Colin Clyne ${ }^{5}$, Xavier Fernandez ${ }^{4}$, Tânia Beatriz Creczynski-Pasa ${ }^{2}$ and Dieudonné Njamen ${ }^{3,6^{*}}$

\begin{abstract}
Background: Ficus umbellata is a medicinal plant previously shown to endow estrogenic properties. Its major component was isolated and characterized as 7-methoxycoumarin (MC). Noteworthy, coumarins and the respective active metabolite 7-hydroxycoumarin analogs have shown aromatase inhibitory activity, which is of particular interest in the treatment of estrogen-dependent cancers. The present work aimed at evaluating the estrogenic/antiestrogenic effects of $M C$ in vitro and in vivo.

Methods: To do so, in vitro assays using E-screen and reporter gene were done. In vivo, a 3-day uterotrophic assay followed by a postmenopausal-like rat model to characterize MC as well as F. umbellata aqueous extract in ovariectomized Wistar rats was performed. The investigations focused on histological (vaginal and uterine epithelial height) and morphological (uterine wet weight, vagina stratification and cornification) endpoints, bone mass,

biochemical parameters and lipid profile.

Results: MC induced a significant $(p<0.05)$ MCF-7 cell proliferation at a concentration of $0.1 \mu \mathrm{M}$, but did not inhibit the effect induced by estradiol in both E-screen and reporter gene assays. In vivo, MC treatment did not show an uterotrophic effect in both rat models used. However, MC $(1 \mathrm{mg} / \mathrm{kg})$ induced a significant increase $(p<0.01)$ of vaginal epithelial height. No significant change was observed with $M C$ in abdominal fat weight, serum lipid levels and bone weight.

Conclusion: These results suggest that MC has a weak estrogenic activity in vitro and in vivo that accounts only in part to the estrogenicity of the whole plant extract. MC could be beneficial with regard to vagina dryness as it showed a tissue specific effect without exposing the uterus to a potential tumorigenic growth.
\end{abstract}

Keywords: Ficus umbellata, 7-methoxycoumarin, Phytoestrogens, E-screen assay, Uterotrophic assay

\section{Background}

Menopause is an inevitable phenomenon occurring naturally in women, characterized by a drop in estrogen levels and a definite cessation of menstruation [1]. It sets around the age of 50 years or following total ovariectomy and affects all women, independent of race and/or social strata [2]. Menopause marks the end of the reproductive life span of women and is often associated with

\footnotetext{
* Correspondence: stephanezingue@gmail.com; dnjamen@gmail.com 'Department of Life and Earth Sciences, Higher Teachers' Training College, University of Maroua, P.O. Box 55, Maroua, Cameroon

${ }^{3}$ Department of Applied Chemistry, Faculty of Science, University of Johannesburg, Doornfontein 2028, South Africa

Full list of author information is available at the end of the article
}

a variety of physiological disorders like hot flushes, depressions and body weight increase. Although such disorders are not life threatening; the social life, as well as, the productivity of the women affected might be negatively impacted [3]. In the long term, estrogen deficiency affects bone density [4] and the cardiovascular system [5]. Hormone replacement therapy (HRT) has therefore been proposed as a solution to postmenopausal symptoms. It is especially effective for the treatment of severe vasomotor and estrogen-deficiency mucosal symptoms, as well as in slowing down the rate of bone demineralization [6]. However, Women's Health Initiative and the British Million Women Studies 
reported that HRT is associated with higher incidence of mammary cancers and arteriosclerotic complications such as heart attack and stroke [7]. This raises questions about the exclusive beneficial effects of HRT [8]. Emerging evidence tends to support the short-term use of HRT for severe menopausal symptoms and its avoidance for long-term prophylaxis [9]. Many menopausal women have therefore turned to non-hormonal therapies [10]. Nowadays, there is the vigorous promotion of plantderived phytoestrogens in a bid to seek for alternatives to HRT. The structural similarity of phytoestrogens to endogenous estradiol permits them to bind and activate estrogen receptors in mammals. The considerable scientific effort is being placed in a search for phytoestrogens that could exhibit optimal estrogenic activity, i.e. with positive effects on bone health while having little effect on uterine or breast tissues [11]. Ficus umbellata Vahl (Moraceae) is a tree that grows in tropical areas; commonly called "Tol'l" in "Ewondo" or "Mewed" in "Guiziga". The bark of $F$. umbellata is used to treat menopause related physiological disorders [12]. In our previous work, aqueous and methanol extracts of $F$. umbellata transactivated the Estrogen Receptor $\alpha(E R \alpha)$ in a reporter gene assay and induced significant estrogen-like effects on estrogen target organs (uterus, vagina and mammary gland) in rats. Furthermore, it significantly decreased the frequency of hot flushes in experimental rats. Its major component was isolated and characterized as 7-methoxycoumarin (MC) [13]. Coumarins consist of a group of compounds characterized by 1,2-benzopyrone or benzopyran-2-ones, which are extensively studied. A number of coumarins exhibit interesting pharmacological activities and are therefore of therapeutic use [14]. Indeed, some coumarins and their active metabolite 7-hydroxycoumarin analogs have shown aromatase inhibitory activity, which is of particular interest in the treatment of estrogen-dependent cancers (ovaries, uterus and breast cancers) $[15,16]$. Preliminary in vitro tests performed with this compound showed that it failed to transactivate ER $\alpha$ and ER $\beta$ in a reporter gene assay [13]. In the present study, in depth in vitro estrogenic assay and a 3-day uterotrophic assay in ovariectomized adult rats were performed to characterize the effects of MC. Thereafter, the effects of $\mathrm{MC}$ as well as $F$. umbellata aqueous extract were evaluated using a postmenopausal-like rat model.

\section{Methods}

\section{Chemicals}

Mass Spectroscopy (MS) grade methanol, acetonitrile $(\mathrm{ACN})$, water and formic acid (FA) were purchased from Sigma-Aldrich (Saint-Quentin Fallavier, France). Fetal bovine serum (FBS) and antibiotics were purchased from GIBCO (Grand Island, NY). The 17ß-estradiol benzoate
[(Estr-1,3,5(10)-trien-3,16 $\alpha, 17 \beta$-triol); purity $298 \%$ ] was obtained from Sigma-Aldrich (Hamburg, Germany). Estradiol valerate (Progynova $^{\circ} 2 \mathrm{mg}$ ) was purchased from DELPHARM (Lille, France). The 2-[4-(2-hydroxyethyl)piperazin-1-yl]ethane sulfonic acid (HEPES, purity $299.5 \%$ ) was purchased from Ludwig Biotecnologia Ltda (Alvorada, RS, Brazil). Trypan blue, Sulforodamine B, Serum Replacement 2 and cell culture mediums were purchased from Sigma-Aldrich (St. Louis, MO, USA). Genistein was obtained from "Extrasynthese" (Genay, France).

\section{Plant material and preparation of $F$. umbellata extracts}

Stem barks of $F$. umbellata were harvested in Yaounde (Centre region, Cameroon) in September 2013. This botanical sample was authenticated by Mr. Victor Nana, a botanist at the National Herbarium of Cameroon (HNC) by comparison to the specimens deposited under the voucher number 99/HNC. After drying under the shade in an aerated place for 2 weeks, the well-dried stem barks of $F$. umbellata were pulverized by electronic grinding. Then, $2 \mathrm{~kg}$ of powder was macerated in water at room temperature $(5 \mathrm{~L}$ of solvent $\times 3,48 \mathrm{~h}$ per extraction). Thereafter solutions were filtered through Whatman paper $\mathrm{N}^{\circ} 4$ and evaporated using an oven with ventilation $\left(40{ }^{\circ} \mathrm{C}\right.$, during $48 \mathrm{~h}$ ) to yield $229.8 \mathrm{~g}$ of aqueous crude extract. Likewise, $2.7 \mathrm{~kg}$ of the powder was macerated in $95 \%$ methanol at room temperature ( $5 \mathrm{~L}$ of solvent $\times 3,48 \mathrm{~h}$ per extraction). The combined solutions were evaporated under reduced pressure (337 mbar at $40{ }^{\circ} \mathrm{C}$ ) using a rotary evaporator to yield $162 \mathrm{~g}$ of a methanol crude extract $(\mathrm{MeOH})$.

\section{Isolation of 7-methoxycoumarin (MC)}

The different Ultra Performance Liquid Chromatography (UPLC) chromatograms of $F$. umbellata aqueous and methanol extracts showed that MC is their major compound. The MC was then isolated after a bio-guided fractionation of $F$. umbellata methanol extract as previously reported [13]. The physicochemical properties of $\mathrm{MC}$ are summarized in Table 1.

\section{UPLC-ESI-MS analyses of $F$. umbellata}

Analyses of $F$. umbellata extracts were performed by UPLC-high resolution electrospray ionization MS (HRESIMS) on an ACQUITY UPLC $/ \mathrm{Xevo}^{\text {tm }}$ G2 QTof (Waters, USA). All separations were performed on an Acquity UPLC BEH C-18 column $(100 \mathrm{~mm} \times 2.1 \mathrm{~mm}$ I.D., $1.7 \mu \mathrm{m}$ ) at $25{ }^{\circ} \mathrm{C}$ with a flow rate of $0.400 \mathrm{~mL} / \mathrm{min}$. A guard column $(5 \mathrm{~mm} \times 2.1 \mathrm{~mm}, 1.7 \mu \mathrm{m})$ with the same stationary phase was placed before the column. The mobile phase consisted of water $+0.1 \%$ FA (solvent A) and $\mathrm{ACN}+0.1 \% \mathrm{FA}$ (solvent B) and was used in multistep gradient mode. The gradient was operated as 
Table 1 General information on 7-methoxycoumarin isolated from F. umbellata

Code and names
$\begin{aligned} & \text { 7-methoxycoumarin } \\ & \text { Methylumbelliferone }\end{aligned}$

follows: $0-1 \mathrm{~min}, 5 \% \mathrm{~B}$; 1-9 $\mathrm{min}, 5-40 \% \mathrm{~B}$; 9-15 $\mathrm{min}$, $40-100 \%$ B. The injection loop was set at $0.5 \mu \mathrm{L}$ and $10{ }^{\circ} \mathrm{C}$ was used as the sample manager temperature. The standard Acquity PDA module was used for online UV detection in the range of $200-700 \mathrm{~nm}$ range, with a resolution of $1.2 \mathrm{~nm}$ and a sampling rate of $10 \mathrm{spectra} / \mathrm{s}$. The HRMS and HRMS/MS data were acquired in negative mode with a mass range of $100-1500 \mathrm{~m} / \mathrm{z}$. The ESI conditions operated were as follows: source temperature $120{ }^{\circ} \mathrm{C}$, desolvation temperature $500{ }^{\circ} \mathrm{C}$; capillary voltage $1.5 \mathrm{KV}$, cone voltage $10 \mathrm{~V}$. Nitrogen was used as a cone $(10 \mathrm{~L} / \mathrm{Hr})$ and desolvation gases $(1000 \mathrm{~L} / \mathrm{Hr})$. Lockspray flow rate was set at $20 \mu \mathrm{L} / \mathrm{min}$ and lockspray capillary at $2.5 \mathrm{KV}$. For the HRMS/MS acquisitions, a method including the detection (full scan) and fragmentation of the most intense peaks per scan was used. The collision energy varied from 10 to $35 \mathrm{~V}$.

\section{In vitro experiments}

\section{Cell line systems}

The MCF-7 - human ER-positive breast adenocarcinoma cell line was obtained from the Rio de Janeiro Cell Bank (Federal University of Rio de Janeiro, Brazil). Human Embryonic Kidney 293 T (HEK 293 T) cell line expressing the SV40 large T-antigen was obtained from ATCC (The Global Bioresource Center, Australia). The luciferase reporter assay, ER $\alpha$ and ER $\beta$ expression plasmids were kindly provided by Dr. Simon Chu (Hudson Institute of Medical Research, Australia). Cells were transfected using Lipofectamine Reagent obtained from Invitrogen (Sydney, Australia).

\section{Cell culture}

MCF-7 cells were cultured in RPMI-1640 medium supplemented with fetal bovine serum (FBS) 10\%. Cell cultures were also supplemented with penicillin $100 \mathrm{U} / \mathrm{mL}$, streptomycin $100 \mu \mathrm{g} / \mathrm{mL}$ and HEPES $10 \mathrm{mM}$. They were maintained at $37{ }^{\circ} \mathrm{C}$ in a $\mathrm{CO}_{2} 5 \%$ humidified atmosphere and $\mathrm{pH} 7.4$. Every 2 days, cells were passaged by removing $90 \%$ of the supernatant and replaced by fresh medium. Viable cells (a minimum of 95\%) were checked at the beginning of the experiment by Trypan Blue dye exclusion test.

HEK293T cells were routinely maintained in Dulbecco's Modified Eagle Medium (DMEM) supplemented with sodium pyruvate $1 \mathrm{mM}$, glutamine $4 \mathrm{mM}, 4.5 \mathrm{~g} / \mathrm{l}$ of glucose, and fetal bovine serum $10 \%$ in a humidified atmosphere at $37{ }^{\circ} \mathrm{C}$ in a $\mathrm{CO}_{2} 5 \%$. Prior to transfection, the media was replaced by the $5 \%$ Charcoal Stripped Serum DMEM phenol free. Cells were then seeded at the density of 50,000 per well in a 24 well-plate format. The next day, they were transfected with appropriate plasmids in the starving media $\mathrm{O} / \mathrm{N}$ and treated in the same media.

\section{E-screen assay}

The E-screen MCF-7 cells proliferation assay was performed as described by Resende et al. [17]. Briefly, cells were trypsinized and seeded in 24-well plates at an initial concentration of $5 \times 10^{4}$ cells per well in RPMI supplemented with FBS $10 \%$. After $24 \mathrm{~h}$ of incubation $\left(37{ }^{\circ} \mathrm{C}, \mathrm{CO}_{2} 5 \%\right)$ to permit their adhesion, cells were washed with phosphate-buffered saline-PBS $(\mathrm{NaCl}$ $137 \mathrm{mM} ; \mathrm{KCl} 2.7 \mathrm{mM} ; \mathrm{Na}_{2} \mathrm{HPO}_{4} 10 \mathrm{mM}$; $\mathrm{KH}_{2} \mathrm{PO}_{4}$ $1.8 \mathrm{mM}$; pH 7.4) and the Serum Replacement $2(0.5 \times)$ supplemented phenol red-free RPMI was substituted for the seeding medium. A stock solution of 7methoxycoumarin $100 \mathrm{mM}$ prepared in DMSO was then added to the experimental medium in order to reach concentrations from $1 \times 10^{-8}$ to $1 \times 10^{-5} \mathrm{M}$. The DMSO concentration of $0.01 \%$ was fixed based on the final volume on different wells. For antiestrogenic evaluation, before cell incubation, $17 \beta$-estradiol $1 \times 10^{-8} \mathrm{M}$ was added to the wells. Cells treated with DMSO (0.01\%) and FBS $10 \%$ in RPMI served as solvent and medium controls, respectively. The assay was stopped after $144 \mathrm{~h}$ by removing the medium from the wells, fixing the cells with cold trichloracetic acid $10 \%$ and incubated at $4{ }^{\circ} \mathrm{C}$ for $1 \mathrm{~h}$. Thereafter, cells were washed four times with tap water and dried. Cells were stained for $30 \mathrm{~min}$ with sulforhodamine-B (SRB) $0.057 \%(w / v)$ which was dissolved in $1 \%$ acetic acid, rinsed four times with acetic acid $1 \%$ and air-dried. Bound dye was solubilized with 
Tris base $10 \mathrm{mM}(\mathrm{pH}$ 10.5) in a shaker. Finally, aliquots were read in a Biotek EL800 absorbance reader (Winooski, USA) at $510 \mathrm{~nm}$. The results related to estrogenic activity were expressed as mean \pm standard error of the mean (SEM) of the proliferative effect (PE), which was calculated according to Schiliro'et al. [18]: $P E=\max$ cell number of sample/cell number of DMSO control. The estrogenic activity of a sample was determined as the relative proliferative effect (RPE\%). The RPE compares the maximum proliferation induced by a sample with that induced by $17 \beta$-estradiol: $R P E \%=[P E$ for sample/PE for $17 \beta$-estradiol] $\times 100$ [17].

\section{Transfections and luciferase assays}

As far as the MC failed to transactivate estrogen receptors $\alpha$ and $\beta$, in the Human Embryonic Kidney $293 \mathrm{~T}$ cell line (HEK293T) transiently transfected with adequate plasmids using Lipofectamine Reagent as thoroughly described by Zingue et al. [13]. The present experiment was aimed to evaluate the possible antiestrogenic effects of this compound in the same cell system and at the concentrations used in our previous study [13]. Briefly, HEK293T cells were transiently transfected with $200 \mathrm{ng}$ of estrogen $\alpha$-receptor plasmid or estrogen $\beta$-receptor expression plasmid, together with the double estrogen response element (ERE) and a luciferase reporter [250 ng (ERE)2-tk-Luc] plasmid kindly provided by Dr. Simon Chu (Hudson Institute of Medical Research, Melbourne, Australia) and $\beta$-galactosidase reporter plasmid using Lipofectamine Reagent (Invitrogen, Mulgrave, Australia). They were then treated with different concentrations $\left(1 \times 10^{-8}\right.$ to $\left.1 \times 10^{-5} \mathrm{M}\right)$ of the $\mathrm{MC}$ in combination with E2 for $24 \mathrm{~h}$ prepared from a $100 \mathrm{mM}$ stock dissolved in $70 \%$ Ethanol. E2 alone or in combination with ICI 182,780 were used as positive control. Reporter gene assays in HEK293T-ER $\alpha$ cells and HEK293T-ER $\beta$ cells were done using a commercial kit (Promega, Melbourne, Australia) according to the manufacurer's instructions. Luciferase activity was measured and normalized toward $\beta$-galactosidase activity determined by using the 2-nitrophenyl b-d-galactopyranoside (ONPG) method (Sigma-Aldrich, Sydney, Australia).

\section{In vivo experiments}

\section{Animals}

Healthy juvenile female Wistar rats aged 3 months ( $\sim 150 \mathrm{~g})$ were obtained from the breeding facility of the Laboratory of Animal Physiology, University of Yaounde I (Cameroon). Animals were housed in clean plastic cages at room temperature (around $25{ }^{\circ} \mathrm{C}$ ) under natural illumination (approx. $12 \mathrm{~h}$ light/dark). The animals had free access to a standard soy-free rat chow (Table 2) and water.
Table 2 Rat chow composition

\begin{tabular}{lll}
\hline Content & Mass $(\mathrm{g} / 100 \mathrm{~g})$ & Percentage \\
\hline Corn & 36.467 & $36.5 \%$ \\
Bone flour & 14.587 & $14.6 \%$ \\
Wheat & 36.467 & $36.5 \%$ \\
Fish flour & 4.862 & $4.9 \%$ \\
Crushed palm kernel & 7.293 & $7.3 \%$ \\
Sodium chloride $(\mathrm{NaCl})$ & 0.303 & $0.3 \%$ \\
Vitamin complex $\left(\mathrm{Olivitazol}^{\oplus}\right)$ & 0.018 & $0.02 \%$ \\
\hline
\end{tabular}

\section{Ethical consideration}

The housing of animals and all experiments were approved by the Cameroon Institutional National Ethic Committee, which adopted all procedures recommended by the European Union on the protection of animals used for scientific purposes (CEE Council 86/609; Reg. no. FWA-IRD 0001954).

\section{Determination of doses}

For the in vivo experiments, estradiol benzoate (E2B) and faslodex were administered subcutaneously at the doses of $2 \mu \mathrm{g} / \mathrm{kg}$ and $300 \mu \mathrm{g} / \mathrm{kg}$, respectively as described by Zingue et al. [19]. The well-known phytoestrogen genistein was administered at a dose of $10 \mathrm{mg} / \mathrm{kg}$ [20]. Based on the amount of the 7methoxycoumarin isolated from $F$. umbellata methanol extract, the quantity contained in the optimal dose (200 $\mathrm{mg} / \mathrm{kg}$ ) of this extract was found to be around $1 \mathrm{mg} / \mathrm{kg}$. This dose was framed between the lowest dose of $0.1 \mathrm{mg} / \mathrm{kg}$ and the highest dose of $10 \mathrm{mg} / \mathrm{kg}$.

\section{The 3-day uterotrophic assay}

In this part of the work (Fig. 1a), 50 female Wistar rats aged 2.5 months were bilaterally ovariectomized (OVX) using the dorsal approach under Diazepam and ketamine anesthesia (respectively $10 \mathrm{mg} / \mathrm{kg}$ and $50 \mathrm{mg} / \mathrm{kg}$ BW; i.p.). After 14 days of endogenous hormonal decline, animals were randomly allocated into 10 groups of five animals each $(n=5)$. Group I received vehicle (corn oil) and served as negative control. Group II received estradiol Benzoate (E2B) as standard drug at the dose of $2 \mu \mathrm{g} / \mathrm{kg}$ per day. Group III received estradiol Benzoate (E2B, $2 \mu \mathrm{g} / \mathrm{kg}$ ) co-administered with the pure antiestrogen faslodex (ICI 182,780; $300 \mu \mathrm{g} / \mathrm{kg}$ ). Group IV received genistein as phytoestrogen control at the dose of $10 \mathrm{mg} / \mathrm{kg}$. Group V, VI and VII received 7methoxycoumarin (MC) at doses of $0.1,1$ and $10 \mathrm{mg} / \mathrm{kg}$, respectively. The remaining three groups (group VIII, IX and $\mathrm{X}$ ) were co-treated with estradiol Benzoate (E2B, $2 \mu \mathrm{g} / \mathrm{kg}$ ) and $\mathrm{MC}$ at doses of $0.1,1$ and $10 \mathrm{mg} / \mathrm{kg}$, respectively. Estradiol benzoate, faslodex (ICI, 182,780), $\mathrm{MC}$ and genistein were dissolved in vehicle (corn oil). 


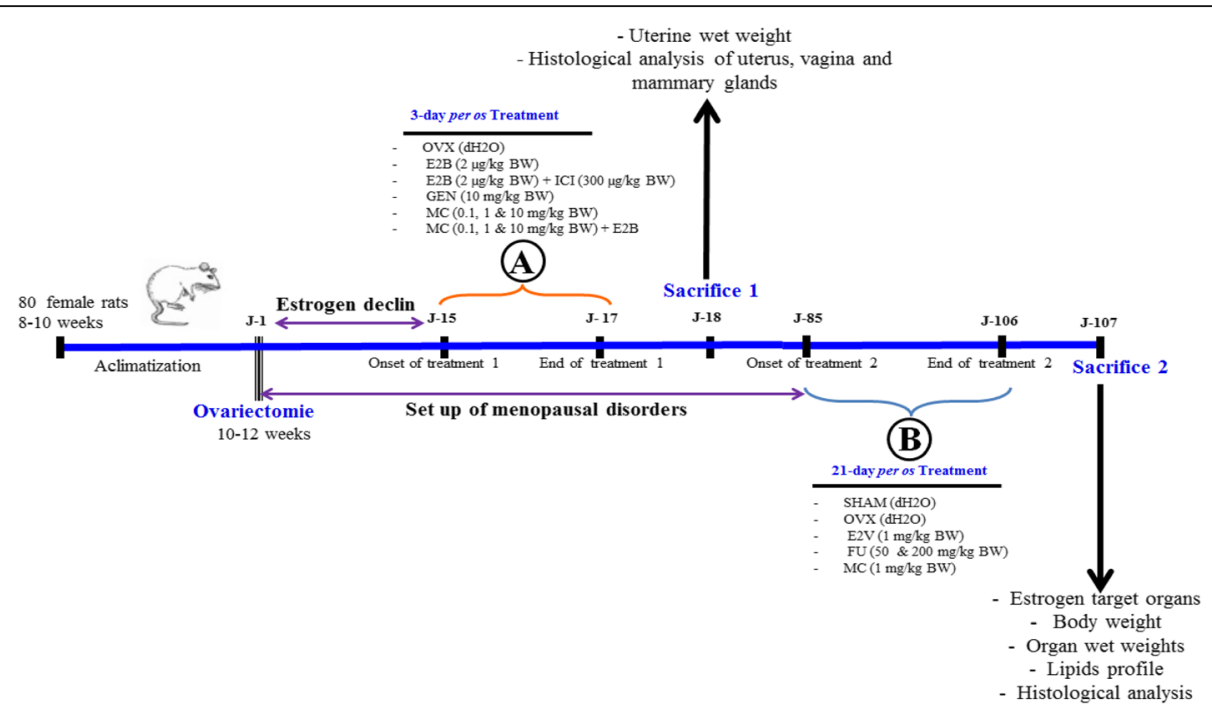

Fig. 1 Scheme of the experimental protocol. Experimental protocol for a 3-day uterotrophic assay (a) and 21-day treatment in a postmenopausal-like rat model (b)

All treatments were given by subcutaneous route $(0.3 \mathrm{~mL} / 150 \mathrm{~g})$ for 3 consecutive days. Twenty-four hours after the last injection, animals were euthanized. The uterine wet weight, uterine and vaginal epithelial heights were assessed as described before by Zingue et al. [13].

\section{Postmenopausal-like rat model}

Five animals were sham-operated under Diazepam and ketamine anesthesia (respectively $10 \mathrm{mg} / \mathrm{kg}$ and $50 \mathrm{mg} /$ $\mathrm{kg} \mathrm{BW}$; i.p.) and 25 other rats were bilaterally ovariectomized as described above (Fig. 1b). Eighty four (84) days after ovariectomy after the onset of postmenopausal-like conditions in rat [21], animals were randomly distributed into six groups of 5 animals each $(n=5)$. Group I (SHAM) was sham operated rats and received distilled water. Group II to VI were ovariectomized rats treated as follows: Group II received distilled water as a negative control (OVX). Group III served as positive control and received estradiol valerate $(1 \mathrm{mg} / \mathrm{kg})$. Group IV received the $\mathrm{MC}$ at the dose of $1 \mathrm{mg} / \mathrm{kg}$ and remaining Group V and VI the F. umbellata aqueous extract at the doses of 50 and $200 \mathrm{mg} / \mathrm{kg}$. All substances were dissolved in distilled water and administered by oral gavage route $(2 \mathrm{~mL} / 250 \mathrm{~g})$ for 21 consecutive days. Throughout the experiment, animals were weighed once every week in order to determine the weight gain. Twenty-four hours after the last treatment, animals were euthanized and blood samples were collected and centrifuged at $3000 \times \mathrm{g}$ for $15 \mathrm{~min}$ and serums were stored at $-4{ }^{\circ} \mathrm{C}$ for further analysis. The uterine, vagina, mammary gland, abdominal fat, liver, lungs, kidneys, adrenergic gland, femur and tibia were collected, cleaned of the superficial fatty layer and weighed. Femurs were dried at $110{ }^{\circ} \mathrm{C}$ for $12 \mathrm{~h}$ and weighed. All collected organs were fixed in 10\% formalin for histological analysis.

\section{Histological analysis}

The histomorphology of the uterus, vagina, femur, liver, lungs and kidneys was performed from $5-\mu \mathrm{m}$ sections of paraffin-embedded tissues following hematoxylin-eosin staining. Organs were photographed at $40 \times$ magnification using the complete Zeiss equipment consisting of a microscope Axioskop 40 connected to a computer where the image was transferred, and analyzed with the MRGrab1.0 and Axio Vision 3.1, both Zeiss (Hallbermoos, Germany) software's'.

\section{Biochemical analysis}

Total-cholesterol, HDL-cholesterol, and triglycerides blood levels were determined enzymatically using reagent-kits purchased from Biolabo (France). The artherogenic index was calculated as total cholesterol on HDL cholesterol.

\section{Statistical analysis}

Results were presented as means \pm standard error of the mean (SEM). In vitro experiments were performed in triplicates and repeated three times. Data analysis was performed with GraphPad Prism 6.0 software, using the ANOVA test followed by the Dunnett's post hoc test to compare each treatment with a control group. Differences were considered significant at a probability level of $5 \%(p<0.05)$. 


\section{Results}

Phytochemical analysis of $F$. umbellata extract by UHPLC-HRMS/MS

A qualitative analysis of the F. umbellata extract was performed using UHPLC-HRMS/MS by electrospray ionization in negative mode. Compound identification was based on their retention time, elemental composition (EC), monoisotopic mass of the pseudomolecular ion $(\mathrm{m} / \mathrm{z})$, RDBeq values, and their major HRMS/MS fragments. All well resolved peaks in TIC was selected and possible EC were calculated. The compounds detected in the methanol extract are summarized in Additional file 1: Table S1 and only eventual estrogenic compounds have been depicted in Fig. 2. A total of 40 secondary metabolites were detected in the active extract of $F$. umbellata belonging to various chemical classes including hydroxybenzoic acids, hydroxycinnamic acids, coumarins, flavonoids and triterpene derivatives. Among them, 4 were identified or putatively characterized based on the dereplication strategy as eventual estrogenic compounds (Fig. 2). In this study, we confirmed the presence of 7-methoxycoumarin at $\mathrm{m} / z$ 175.0384 (Rt $6.0 \mathrm{~min}$ ) already described in our previous work as the major component of F. umbellata [13], but also other coumarins such as dihydroxycoumarin at $\mathrm{m} / \mathrm{z}$ 177.0184 (Rt $6.35 \mathrm{~min}$ ) and prenyl-7-hydroxycoumarin at 229.0865 (Rt $9.01 \mathrm{~min}$ ). Genistein (Rt $6.55 \mathrm{~min}, \mathrm{~m} / \mathrm{z} 269.0446$ ) and biochanin A (Rt $8.89 \mathrm{~min}, \mathrm{~m} / z$ 283.0607) already described in F. carica [22] were identified based on their MS/MS fragmentation patterns.

\section{In vitro estrogenicity assessment \\ E-screen assay}

In the Fig. 3a is shown a significant $(p<0.001)$ increase by $17-\beta$ estradiol-induced in MCF-7 cells proliferation. The MC induced a significant $(p<0.05)$ MCF-7 cells proliferation only at the concentration of $0.1 \mu \mathrm{M}$ as compared to DMSO control. No antiestrogenic activity was noted with all tested concentrations of MC in this assay.

\section{Transactivation assay}

The Fig. $3 \mathrm{~b}$ and $\mathrm{c}$ showed that $\mathrm{MC}$ failed to inhibit the transactivation of $E R \alpha$ as well as ER $\beta$ induced by estradiol (E2). No significant change was observed with the co-treatment $\mathrm{MC}$ plus estradiol, suggesting that it has no antiestrogenic properties.

\section{In vivo estrogenicity assessment}

\section{Effects on uterus}

Figure 4 depicts that E2B induced a significant $(p<0.001)$ increase in the uterine wet weight as well as in the uterine epithelial height as compared to the OVX group. The pure antiestrogen faslodex significantly $(p<0.001)$ abolished the effects of E2B. Genistein, a well characterized phytoestrogen did not exert significant changes in uterine wet weight whereas, it induced a significant $(p<0.05)$ increase

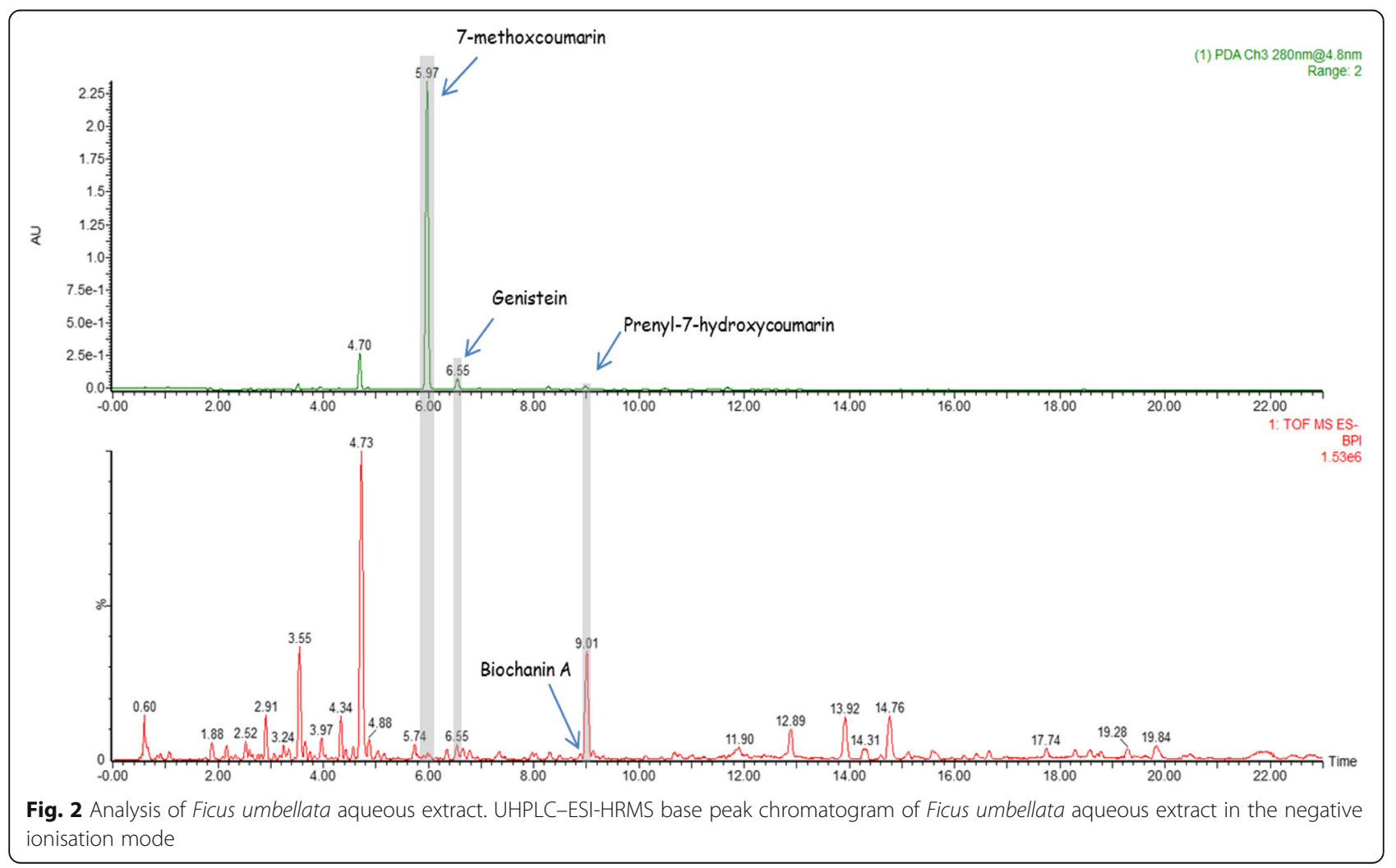




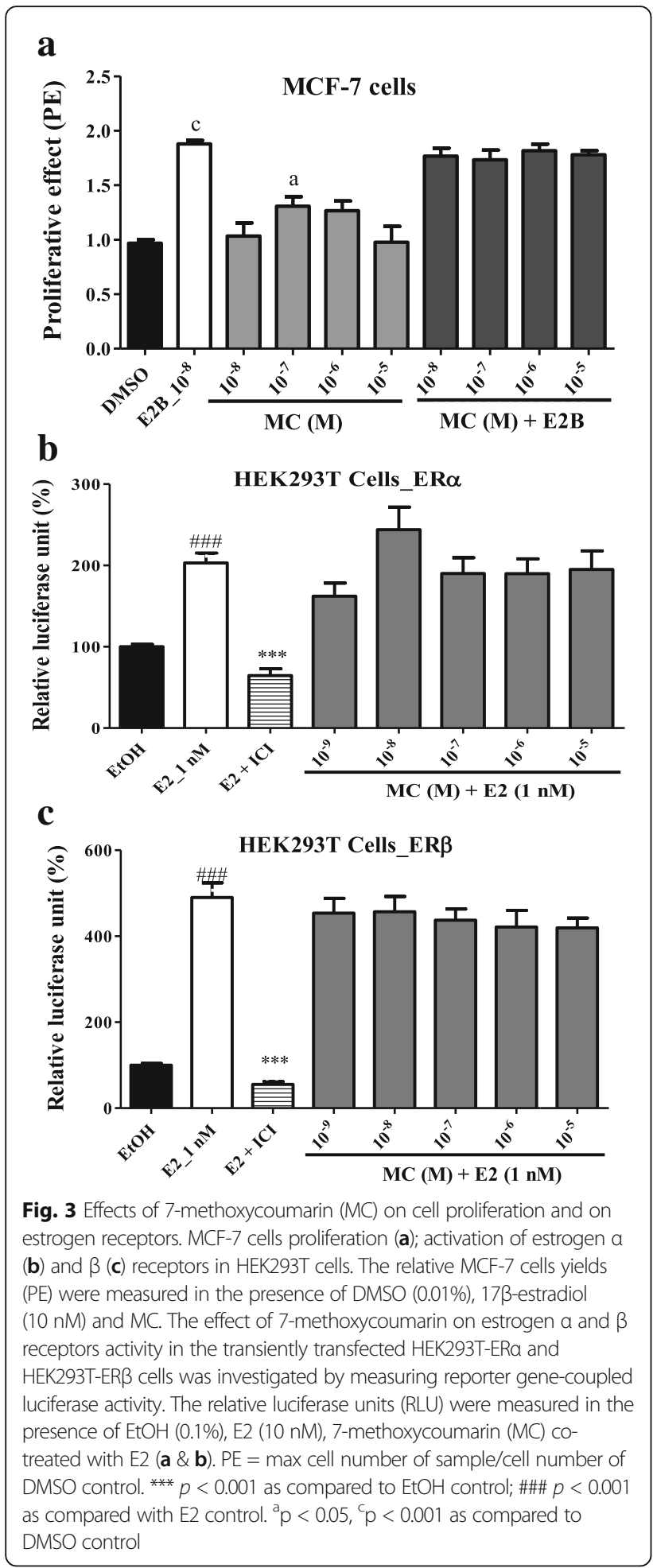

in uterine epithelial height. No estrogenic effects were noted following the treatment with $\mathrm{MC}$ in the uterus at all tested doses. However, MC $(0.1 \mathrm{mg} / \mathrm{kg})$ induced a significant $(p<0.05)$ decrease in the endometrium height when co-administered with E2B (Fig 4b).

\section{Effects on vagina}

The effects observed following a 3-day treatment with different substances on the vagina are shown in Fig. 5. There was a significant increase in the vaginal epithelium height with E2B $(p<0.001)$ and genistein $(p<0.01)$ treatments, while co-treatment of the E2B and Faslodex significantly $(p<0.001)$ abolished the effects of estradiol on vaginal epithelium. The MC induced a significant increase $(p<0.01)$ in the vaginal epithelium height only at the dose of $1 \mathrm{mg} / \mathrm{kg}$. No antiestrogenic activity was noted on vagina epithelium with $\mathrm{MC}$.

\section{Effect of 7-methoxycoumarin and $F$. umbellata extract on postmenopausal symptoms}

\section{Effects on estrogen target organs}

Effects of different treatments on estrogen target organs in postmenopausal-like conditions are summarized in Table 3. An 84-day post-ovariectomy induced a significant $(p<0.001)$ reduction in uterine wet weight, uterine and vaginal epithelial heights. E2V significantly $(p<0.001)$ increased the uterine wet weight as well as uterine and vaginal epithelial heights. There was no change on the uterine wet weight as well as the uterine epithelial height upon administration of $F$. umbellata aqueous extract. Interestingly, $F$. umbellata aqueous extract at both doses (50 and $200 \mathrm{mg} / \mathrm{kg}$ ) as well as MC (1 mg/ $\mathrm{kg}$ ) significantly $(p<0.01)$ increased vaginal epithelial height as compared to control OVX (Table 3).

\section{Fasting serum lipids}

A slight but significant $(p<0.05)$ increase in fasting serum total cholesterol levels and triglycerides levels (Table 3) was observed in animals of OVX group compared to sham operated animals, while the HDLcholesterol levels significantly $(p<0.01)$ decreased (Table 3). Hence, the atherogenic risk, calculated as the ratio of total cholesterol to HDL-cholesterol increased. The E2V group $(1 \mathrm{mg} / \mathrm{kg} \mathrm{BW})$ significantly $(p<0.05)$ decreased triglycerides and total cholesterol levels, while it increased HDL-cholesterol level after 21 days of treatment. F. umbellata aqueous extract at the dose of $200 \mathrm{mg} / \mathrm{kg} \mathrm{BW}$ on the other hand decreased total cholesterol and increased HDL-cholesterol levels as compared to the control. Moreover, the artherogenic risk was significantly decreased by E2V and the methanol extract of F. umbellata at the dose of $200 \mathrm{mg} / \mathrm{kg} \mathrm{BW}$. The 7-methoxycoumarin did not induce significant changes in fasting serum lipids (Table 3).

\section{Effects on body weight and relative organ weights}

Body weight of all animals increased after the ovariectomy. Table 4 displays only the variation of body weight during the period of treatment. A significant $(p<0.05)$ increase in the body weight between the onsets of 


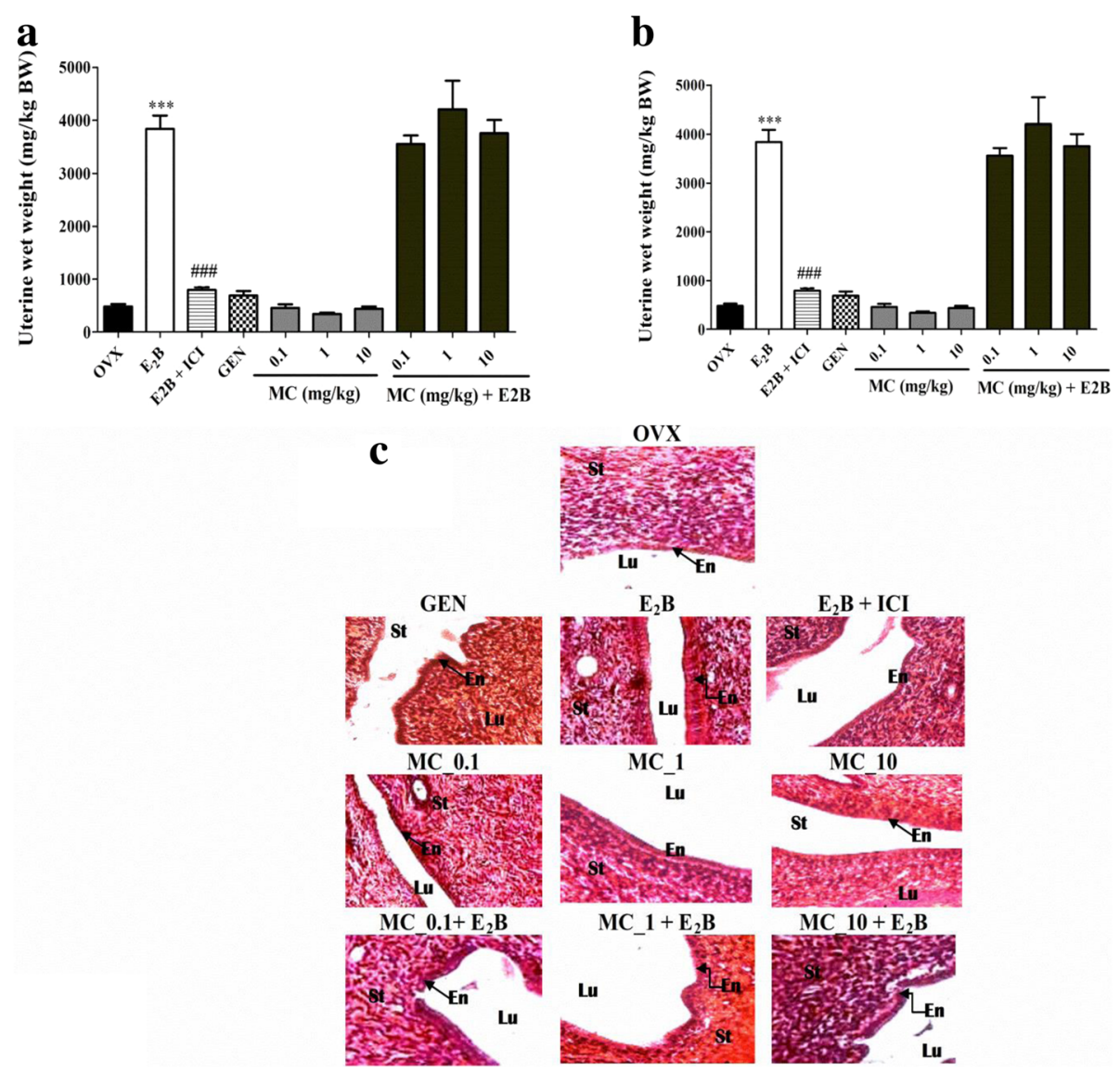

Fig. 4 Analysis of the rat uterus. Graphic representations of uterine wet weight (a), uterine epithelial height (b) and microphotographs of H\&E-stained sections (400X) of uterus (c). OVX = Ovariectomized rat treated with vehicle; $E_{2} B=$ Ovariectomized rat treated with estradiol benzoate at the dose of $2 \mu \mathrm{g} / \mathrm{kg}$. $\mathrm{E}_{2} \mathrm{~B}+\mathrm{ICl}=$ Ovariectomized rat CO-administered with estradiol benzoate $(1.75 \mu \mathrm{g} / \mathrm{kg})$ and $\mathrm{ICl}, 182.780(300 \mu \mathrm{gg} / \mathrm{kg})$. GEN = Ovariectomized rat treated with genistein at the dose of $10 \mathrm{mg} / \mathrm{kg} \mathrm{BW} . \mathrm{MC}=$ Ovariectomized rat treated with 7-methoxycoumarin at the doses of $0.1,1 \mathrm{and} 10 \mathrm{mg} / \mathrm{kg}$ $\mathrm{BW} . \mathrm{MC}+\mathrm{E}_{2} \mathrm{~B}=$ Ovariectomized rat co-administered with estradiol benzoate $(1.75 \mu \mathrm{g} / \mathrm{kg})$ and $\mathrm{MC}$ at the doses of $0.1,1 \mathrm{and} 10 \mathrm{mg} / \mathrm{kg} \mathrm{BW}$. *** $p<0.001$ as compared to OVX group. \#\# $p<0.01$, \#\#\# $p<0.001$ as compared to $\mathrm{E}_{2} \mathrm{~B}$ group. Lu = lumen of uterus; En = endometrium; St = Stroma

treatment until the end with OVX group was noted. A slight decrease in body weight was noted with estradiol treatment (E2V). F. umbellata aqueous extract prevented increase in the body weight.

No change was noted in relative weights of liver, lungs, kidneys and adrenergic glands (Table 4). However, a significant increase in femur wet $(p<0.01)$ and dried $(p<0.001)$ weights as well as in tibia wet weight $(p<0.01)$ with $F$. umbellata treatment at both doses was noted. In addition, a significant decrease of abdominal fat was observed in rats treated with E2V $(p<0.01)$ and F. umbellata aqueous extract at the dose of $200 \mathrm{mg} / \mathrm{kg}$ $(p<0.05)$.

\section{Effects on the microarchitecture of some organs}

No alterations in the microarchitecture of liver, lungs and kidneys were noted in this work (Additional file 1: Figure S2). However, the femur microarchitecture of OVX rats showed bone marrow disparities into the trabecular network. E2V and F. umbellata aqueous extract $(200 \mathrm{mg} / \mathrm{kg})$ treatments prevented bone resorption, evidenced by the inhibition of bone marrow loss into the trabecular network. MC did not induce significant change in the bone microarchitecture.

\section{Discussion}

Coumarins comprise of compounds characterized by 1,2benzopyrone or benzopyran-2-ones, which are extensively studied. Many valuable biological activities have been assigned to coumarins [14]. The 7-methoxycoumarin (MC) used in this study was isolated as the major component of $F$. umbellata. This compound failed to transactivate estrogen receptors (ER $\alpha$ and $E R \beta)$ in vitro in our previous work [13]. However, it was observed in this study that $\mathrm{MC}$ induced a significant proliferation in MCF-7 cells in an E-screen assay at the concentration of $0.1 \mu \mathrm{M}$, while it did not alter MCF-7 cells proliferation when coadministered with estradiol at all tested concentrations. In 
$\mathbf{a}$

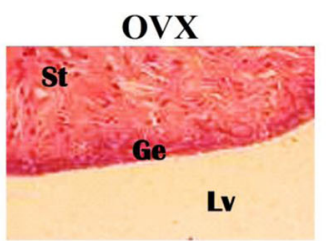

$E_{2} B$

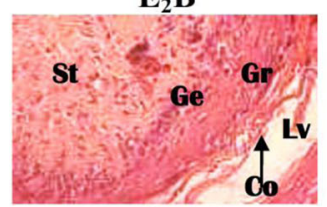

MC 0.1

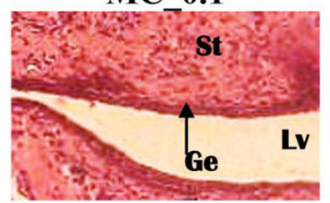

MC $0.1+E_{2} B$

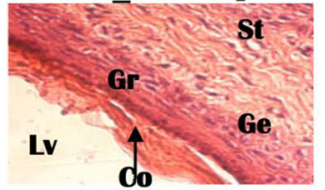

b

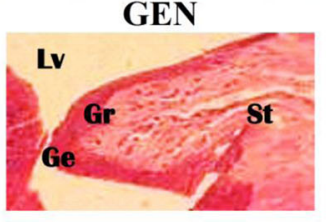

MC_1

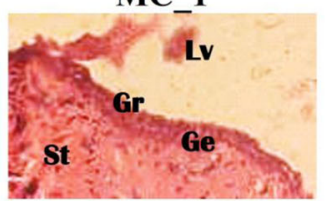

$\mathrm{MC} 1+\mathrm{E}_{2} \mathrm{~B}$

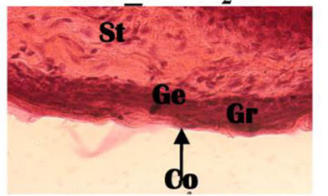

$\mathbf{E}_{2} \mathbf{B}+\mathbf{I C I}$

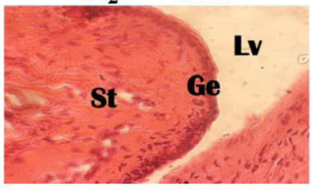

MC_10

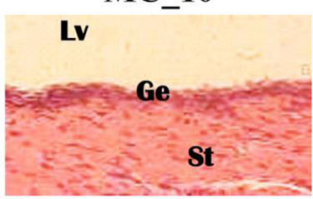

$\mathrm{MC} \_10+\mathrm{E}_{2} \mathrm{~B}$

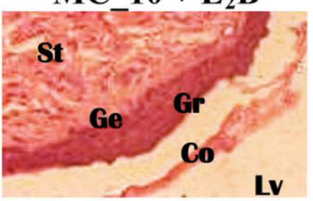

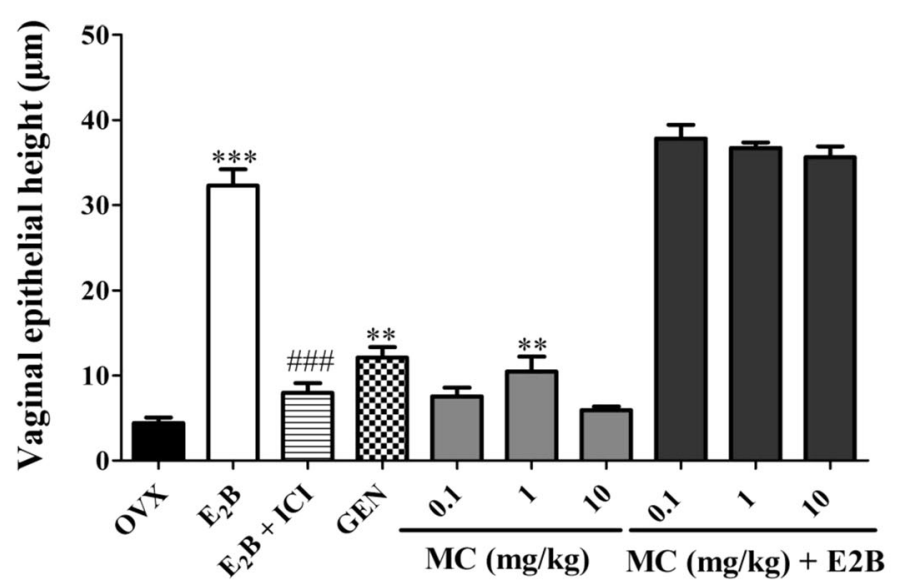

Fig. 5 Analysis of the rat vaginas. Microphotographs of H\&E-stained sections (400X) of vagina (a) and graphic representation of the vaginal epithelial height (b). OVX = Ovariectomized rat treated with vehicle; $E_{2} B=$ Ovariectomized rat treated with estradiol benzoate at the dose of $2 \mu \mathrm{gg} / \mathrm{kg}$. $\mathrm{E}_{2} \mathrm{~B}+\mathrm{ICl}=$ Ovariectomized rat co-administered with estradiol benzoate $(1.75 \mu \mathrm{g} / \mathrm{kg})$ and $\mathrm{ICl}, 182.780(300 \mu \mathrm{g} / \mathrm{kg})$. GEN = Ovariectomized rat treated with genistein at the dose of $10 \mathrm{mg} / \mathrm{kg} \mathrm{BW}$. MC = Ovariectomized rat treated with 7-methoxycoumarin at the doses of $0.1,1 \mathrm{and} 10 \mathrm{mg} / \mathrm{kg}$ BW. $\mathrm{MC}+\mathrm{E}_{2} \mathrm{~B}=$ Ovariectomized rat co-administered with estradiol benzoate $(1.75 \mu \mathrm{g} / \mathrm{kg})$ and 7 -methoxycoumarin at the doses of $0.1,1 \mathrm{and} 10 \mathrm{mg} / \mathrm{kg}$ BW. ${ }^{* *} p<0.01 ;{ }^{* * *} p<0.001$ as compared to OVX group. \#\#\# $p<0.001$ as compared with $\mathrm{E}_{2} \mathrm{~B}$ group. Lu = lumen of uterus;

$\mathrm{En}=$ endometrium; St $=$ Stroma

addition, MC did not alter ER $\alpha$ and ER $\beta$ stably transfected in HEK293T cells when co-administered with estradiol. These observations are consistent with those obtained in the E-screen assay and suggest that MC has a weak estrogen-like effect but no antiestrogenic effects in vitro. The E-screen assay measures cell proliferation, which is well known as a hallmark of estrogen-like activity [23]. The fact that MC induced MCF-7 cell proliferation and failed to transactivate ERs in vitro raises two hypotheses. On one hand, MC might induce its estrogenicity via a non-genomic pathway, since MCF-7 cell proliferation involves both genomic and non-genomic pathways [18]. On the other hand, this compound might undergo hydroxylation by MCF-7 cell enzymes and then bind to ERs such as 6-hydroxycoumarin, which is well known to transactivate ERs [24]. In vivo results show that a 3-day 
Table 3 Effects of 7-methoxycoumarin (MC) and F. umbellata aqueous extract on estrogen target organs and lipids profile on postmenopausal-rat model after 21 days treatment

\begin{tabular}{|c|c|c|c|c|c|c|}
\hline \multirow[b]{2}{*}{ Items } & \multirow[b]{2}{*}{ SHAM } & \multicolumn{5}{|c|}{ Ovariectomized rats } \\
\hline & & OVX & E2V & FU 50 & FU 200 & $\mathrm{MC}$ \\
\hline \multicolumn{7}{|l|}{ Estrogen target organs } \\
\hline Uterine wet weight (mg/kg) & $1921.36 \pm 185.26$ & $356.9 \pm 19.05^{\# \# \#}$ & $1288.42 \pm 136.9^{* * *}$ & $546.12 \pm 44.24$ & $349.69 \pm 7.69$ & $409.83 \pm 15.81$ \\
\hline Uterine epithelial height ( $\mu \mathrm{m})$ & $6.71 \pm 0.36$ & $3.06 \pm 0.16^{\# \# \#}$ & $5.27 \pm 0.15^{* * *}$ & $3.6 \pm 0.37$ & $3.84 \pm 0.18$ & $3.39 \pm 0.20$ \\
\hline Vaginal epithelial height $(\mu \mathrm{m})$ & $19.06 \pm 0.11$ & $2.54 \pm 0.56^{\# \# \#}$ & $14.25 \pm 0.55^{* * *}$ & $6.24 \pm 0.20^{* *}$ & $7.86 \pm 0.01^{* *}$ & $8.56 \pm 1.39 * * *$ \\
\hline \multicolumn{7}{|l|}{ Lipids profile } \\
\hline Total cholesterol level (mg/dL) & $67.92 \pm 6.27$ & $93.9 \pm 2.29^{\# \#}$ & $56.98 \pm 11.27^{*}$ & $83.01 \pm 10.27$ & $56.53 \pm 4.99^{*}$ & $79.24 \pm 11.67$ \\
\hline Triglycerides levels (mg/dL) & $47.96 \pm 3.75$ & $62.96 \pm 7.35^{\#}$ & $44.66 \pm 2.02^{*}$ & $63.01 \pm 6.46$ & $49.48 \pm 1.67$ & $56.08 \pm 4.26$ \\
\hline HDL-Cholesterol level (mg/dL) & $46.62 \pm 0.91$ & $44.91 \pm 0.34^{\#}$ & $45.94 \pm 0.54^{*}$ & $45.1 \pm 0.38$ & $45.60 \pm 0.66^{*}$ & $45.33 \pm 0.44$ \\
\hline Atherogenic risk & $1.28 \pm 0.20$ & $1.63 \pm 0.15^{\#}$ & $1.19 \pm 0.15^{*}$ & $1.84 \pm 0.22$ & $1.19 \pm 0.21 *$ & $1.69 \pm 0.22$ \\
\hline
\end{tabular}

SHAM = Sham operated rats treated with vehicle as normal control; OVX = Ovariectomized rats treated with vehicle as negative control; $\mathrm{E}_{2} \mathrm{~V}=\mathrm{Ovariectomized}$ rats treated with estradiol valerate at the dose of $1 \mathrm{mg} / \mathrm{kg} \mathrm{BW}$; FU 50 and $200=$ Ovariectomized rats treated with $F$. umbellata aqueous extract at the doses of 50 and $200 \mathrm{mg} / \mathrm{kg} \mathrm{BW}$, respectively; MC = Ovariectomized rats treated with 7-methoxycoumarin at the dose of $1 \mathrm{mg} / \mathrm{kg} \mathrm{BW}$. ${ }^{\#} p<0.05$, ${ }^{\# \#} p<0.01$, \#\#\# $p<0.001$ as compared to SHAM group. ${ }^{*} p<0.05,{ }^{* *} p<0.01,{ }^{* * *} p<0.001$ as compared to OVX group

treatment with $\mathrm{MC}$ neither induced estrogenic nor antiestrogenic effects on the uterus. However, a slight but not significant increase in endometrial thickness was observed in vivo, which is consistent with the weak estrogenicity observed with $\mathrm{MC}$ in vitro. The uterus and mammary glands express much ER $\alpha$ than ER $\beta$ [25], which may explain the above observations. These results suggest that $\mathrm{MC}$ is not responsible for the observed estrogenic effects of $F$. umbellata extract on the uterus [13]. Furthermore, MC induced a significant increase in vaginal epithelial height in ovariectomized rats at the dose of $1 \mathrm{mg} / \mathrm{kg}$ after a 3-day treatment. In addition, no estrogenic activity was noted in the uterus after 21 consecutive days of treatment with this compound in the postmenopausal-like rat model, while it induced a significant increase in vaginal epithelial height as it did in the 3-day uterotrophic assay. These results point out a tissue-selective activity for this compound and strengthen our hypothesis that $\mathrm{MC}$ is responsible only in part for the estrogenic activity of $F$. umbellata. 6-hydroxycoumarin, Genistein and Biochanin A detected in $F$. umbellata extract by UPLC-MS in this study are well known phytoestrogens, that might account for its effects on the uterus.

After 21 days of treatment with MC and F. umbellata aqueous extract, no significant changes were noticed on the relative weights of liver, lungs, kidneys, and adrenal glands as well as in the microarchitecture of the liver, lungs and kidneys; suggesting that these substances are weakly toxic. These observations corroborate our previous finding that the LD50 of $F$. umbellata is more than $5000 \mathrm{mg} / \mathrm{kg}$ [13]; thus supporting its use in the traditional medicine. Interestingly, a significant increase in femur wet and dry weights as well as in the tibia wet weight with $F$. umbellata aqueous extract was observed at the dose of $200 \mathrm{mg} / \mathrm{kg}$, while MC failed to induce such effects. Since postmenopausal osteoporosis is a worldwide health problem with a high prevalence [26], these results encourage the exploration of the antiosteoporotic potential of $F$. umbellata extract. Preventive effects of phytoestrogens on postmenopausal osteoporosis are well-known [27]. As far as F. umbellata transactivated ERs in vitro, its components might bind to ERs, which have been localized in osteoblasts and osteoclasts and limit bone reabsorption by inhibiting osteoclasts [28]. It seems that MC does not contribute to the effects of $F$. umbellata aqueous extract in bones.

Estrogen deficiency is associated with dyslipidemia, a major cause of increased risk of developing cardiovascular disease [29]. In this study ovariectomy induced a significant variation of serum total cholesterol levels. Following treatment, E2V decreased the serum total cholesterol levels compared to the negative control (OVX). E2 has been shown to inhibit the hydroxymethylglutaryl coenzyme A (HMG-CoA) reductase in cholesterol biosynthesis as well as the rate-limiting enzyme in the cholesterol synthesis de novo [30], hence reducing the synthesis of cholesterol. Scientific reports point out the evidence that this effect on cholesterol metabolism might be mediated by ER $\alpha$ [31]. Conversely, $\mathrm{MC}$ failed to change fasting serum lipids. However, $F$. umbellata aqueous extract exhibited estrogen-like effects by decreasing fasting serum total cholesterol and increase serum HDL cholesterol levels at a dose of $200 \mathrm{mg} / \mathrm{kg}$. Atherogenic index was used as an indicator of cardiovascular risks. The increase in HDL-Cholesterol levels in E2V-treated animals observed in this work is in accordance with other reports, which demonstrated an increase in HDL-Cholesterol levels following estrogen treatment in humans [32, 33]. Results on atherogenic risks showed that $F$. umbellata but not MC has 


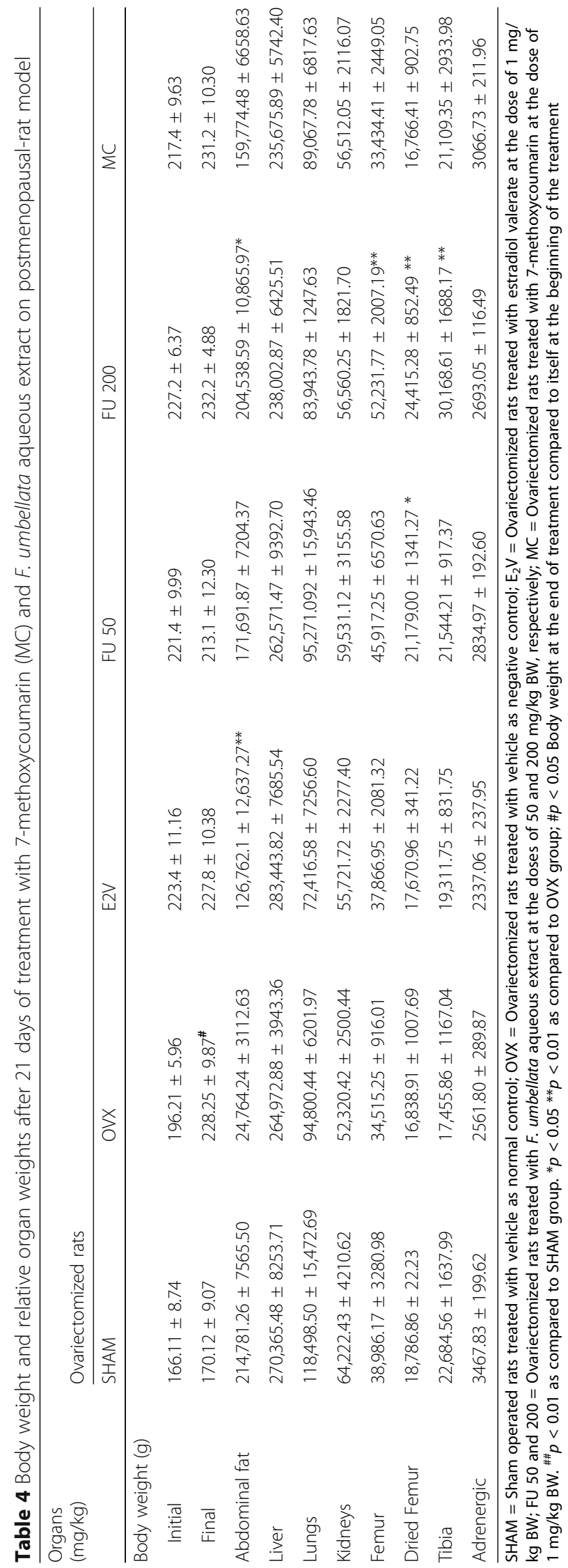


beneficial effects on lipid metabolism. This might be due to its ability to activate ERs and induce the transcription of genes involved in lipid metabolism. F. umbellata extract was found to contain phytoestrogens (Genistein, Biochanin A, hydroxylcoumarin) which may result from the activation of gene transcription through selective binding of phytoestrogens to ER $\alpha$ and ER $\beta$ [34]. Such gene, in turn might display beneficial effects on lipid metabolism in postmenopausal women.

\section{Conclusion}

In conclusion, $\mathrm{MC}$ exhibited a weak estrogen activity in vitro as well as in vivo; suggesting that the estrogenic effects displayed by the whole extract is mostly due to the other phytoestrogens present in the plant. However, MC could be beneficial with regard to vaginal dryness as it showed a tissue specific effect without exposing the uterus to a potential tumorigenic growth.

\section{Additional files}

Additional file 1: Table S1. Summary of compounds separated and identified in F. umbellata aqueous extract by UHPLC-ESI-HRMS analysis in the negative ion mode. Figure S1. Microphotographs of HE-stained sections (400x) of liver, lungs, kidneys and femur from different experimental rat groups in postmenopausal-like condition after 3 weeks of treatment. SHAM = Sham operated rats treated with vehicle as normal control; OVX = Ovariectomized rats treated with vehicle as negative control; $E_{2} V=$ Ovariectomized rats treated with estradiol valerate at the dose of dose $1 \mathrm{mg} / \mathrm{kg}$ BW as positive control; FU 50 and $200=$ Ovariectomized rats treated with $F$. umbellata aqueous extract at the doses of 50 and $200 \mathrm{mg} / \mathrm{kg} \mathrm{BW}$, respectively; $\mathrm{MC}=$ Ovariectomized rats treated with 7-methoxycoumarin at the dose of $1 \mathrm{mg} / \mathrm{kg} \mathrm{BW}$. Vp $=$ portal veine, $\mathrm{H}=$ Hepatocyte; $\mathrm{S}=$ sinusoids; $\mathrm{A}=$ alveol; $\mathrm{Ba}=$ Aveolar bag; $\mathrm{TB}=$ Trabecular bone; $\mathrm{MB}=$ marrow bone; $\mathrm{Mi}=$ microglie; $\mathrm{Ne}=$ Neurone; $\mathrm{Co}=$ Cortex. G = Glomerula; Dt = Distal tube; Pt = Proximal tube. (DOCX 797 kb)

\section{Abbreviations \\ C-hex: Cyclo hexane; CNH: Cameroon National Herbarium; CPC: Centrifugal partition chromatography; DCM: Dichloromethane; DMEM: Dulbecco's Modified Eagle Medium; DMSO: Dimethylsulfoxide; ER: Estrogen receptor; F: Fraction; FBS: Fetal bovine serum; FCS: Fetal calf serum; HEPES: 4-(2- hydroxyethyl)-1-piperazineethane sulfonic acid; HPLC: High Performance Liquid Chromatography; MC: 7-methoxycoumarin; MeOH: Methanol; NMR: Nuclear magnetic resonance; PBS: Phosphate-buffered saline; PE: Proliferative effect; RPMI: Roswell Park Memorial Institute; SRB: Sulforhodamine-B}

\section{Acknowledgments}

The present work has been done with the support from CNPq, Brazilian National Council for Scientific and Technological Development - Brazil and TWAS, the Academy of Sciences for the Developing World (Grant N 190741/2015-5). Authors would thank the ERINI institute (http://www.erini-institute.com/) for the use of their UPLC Xevo G2 QTof apparatus. Authors would also thank Alexander von Humboldt foundation for the material support offered to Dieudonné Njamen.

\section{Funding}

The authors declare that they have not received any funding for this work.

\section{Availability of data and materials}

The data and materials used in this study are available upon request from the authors.

\section{Authors' contributions}

$\mathrm{ZS}$, and ND designed the experiments. ZS and ANN carried out the in vivo part of the study; ZS, MNCB, CJ and CC carried out the in vitro part of the study. TM and DTN carried out the phytochemical part of the study. ZS wrote the manuscript; ND, CC, CPTB and MNCB supervised the work. All authors approved the final manuscript.

\section{Ethics approval and consent to participate}

The housing of animals and all experiments were approved by the Cameroon Institutional National Ethic Committee, which adopted all procedures recommended by the European Union on the protection of animals used for scientific purposes (CEE Council 86/ 609; Reg. no. FWA-IRD 0001954).

\section{Consent for publication}

Not applicable.

\section{Competing interests}

The authors declare that they have no competing interests.

\section{Publisher's Note}

Springer Nature remains neutral with regard to jurisdictional claims in published maps and institutional affiliations.

\section{Author details}

'Department of Life and Earth Sciences, Higher Teachers' Training College, University of Maroua, P.O. Box 55, Maroua, Cameroon. ${ }^{2}$ Department of Pharmaceutical Sciences, Health Sciences Centre, Federal University of Santa Catarina, CEP, Florianópolis, Santa Catarina 88040-900, Brazil. ${ }^{3}$ Department of Applied Chemistry, Faculty of Science, University of Johannesburg, Doornfontein 2028, South Africa. ${ }^{4}$ Institute of Chemistry of Nice, Faculty of Science, University Côte d'Azur, UMR CNRS 7272, Valrose Park, Cedex 2 Nice, France. ${ }^{5}$ Hudson Institute of Medical Research, Clayton, VIC 3168, Australia. ${ }^{6}$ Department of Animal Biology and Physiology, Faculty of Science, University of Yaoundé 1, P.O. Box 812, Yaounde, Cameroon.

Received: 26 February 2017 Accepted: 27 July 2017

Published online: 02 August 2017

\section{References}

1. Davison SL, Bell R, Donath S, Montalto JG, Davis SR. Androgen levels in adult females: changes with age, menopause, and Oophorectomy. J Clin Endocrinol Metab. 2005;90:3847-53.

2. Thomas F, Renaud F, Bebefice E, De Meeus T, Guegan JF. International variability of ages at menarche and menopause: patterns and main determinants. Hum Biol. 2001;7:271-90.

3. Nkwo P, Onah $\mathrm{H}$. Positive attitude to menopause and improved quality of life among Igbo women in Nigeria. Int J Gynecol Obstet. 2008;103:71-2.

4. Mc Clung MR. Prevention and management of osteoporosis. J Clin Endocrinol Metab. 2003;17:53-71

5. Yang XP, Reckelhoff JF. Estrogen, hormonal replacement therapy and cardiovascular disease. Curr Opin Nephrol Hypertens. 2011;20:133-8.

6. Bhavnani BR, Strickler RC. Menopausal hormone therapy. J. Obstet gynecol can. 2005;8:137-62.

7. Rossouw JE, Anderson GL, Prentice RL, LaCroix AZ, Kooperberg C, Stefanick ML. Writing Group for the Women's health initiative investigators: risks and benefits of estrogen plus progestin in healthy postmenopausal women: principal results from the Women's Health Initiative randomized controlled trial. JAMA. 2002;288:321-33.

8. Million Women Study Collaborators. Breast cancer and hormone replacement therapy in the million women study. Lancet. 2003;362:419-27.

9. Skouby SO, Al-azzawi F, Barlow D, Calaf-aldina erdogan ertüngel PJ, Gompel A, Graziottin A, Hudita D, Pines A, Rozenberg S, Samsioe G, Stevenson JC. European menopause and andropause society. Climacteric medicine: european menopause and andropause society (emas) 2004/2005 position statements on peri- and postmenopausal hormone replacement therapy. Maturitas. 2007;56:227-9.

10. Cheema D, Coomarasamy A, El-toukhy T. Non-hormonal therapy of postmenopausal vasomotor symptoms: a structured evidence-based review. Arch Gynecol Obstet. 2007;276:463-9. 
11. Boué SM, Tilghman SL, Elliott S, Zimmerman MC, Williams KY, PaytonStewart F, Miraflor AP, Howell MH, Shih BY, Carter-Wientjes CH, Segar C Beckman BS, Wiese TE, Cleveland TE, McLachlan JA, Burow ME. Identification of the potent Phytoestrogen Glycinol in elicited soybean (Glycine max). Endocrinology. 2009;150:2446-53.

12. Arbonnier M. Arbres, arbustes et lianes des zones sèches d'Afrique de I'Ouest. Editions Quæ RD 10; F- 78026 Versailles Cedex, France; ISBN Quæ 978-2-7592-0313-0; Muséum National d'histoire Naturelle (MNHN); Service des publications scientifiques 2009; 57 Rue Cuvier, F- 75005 Paris, France; ISBN MNHN 978-2-85653-626-1. Pp 396-416.

13. Zingue $S$, Michel T, Tchatchou J, Magne Nde CB, Winter E, Monchot A, Awounfack CF, Djiogue S, Clyne C, Fernandez X, Creczynski-Pasa TB, Njamen D. Estrogenic effects of Ficus umbellata Vahl. (Moraceae) extracts and their ability to alleviate some menopausal symptoms induced by ovariectomy in Wistar rats. J Ethnopharmacol. 2016;179:332-44.

14. De Souza LG, Renn MN, Figueroa-Villar JD. Coumarins as cholinesterase inhibitors: a review. Chem Biol Interac. 2016:254:11-23.

15. Jacquot $Y$, Laïos I, Cleeren A, Nonclercq D, Bermont L, Refouvelet $B$, Boubekeur K, Xicluna A, Leclerca G, Laurent G. Synthesis, structure, and estrogenic activity of 4-amino-3-(2-methylbenzyl)coumarins on human breast carcinoma cells. Bioorg Med Chem. 2007;15:2269-82.

16. Musa MA, Cooperwood JS, Khan MOF. A review of Coumarin derivatives in pharmacotherapy of breast cancer. Curr Med Chem. 2008;15:2664-79.

17. Resende FA, De Oliveira APS, De Camargo MS, Vilegas W, Varanda EA. Evaluation of estrogenic potential of Flavonoids using a recombinant yeast strain and MCF7/BUS cell proliferation assay. PLoS One. 2013;8:74881.

18. Schiliro T, Gorrasi I, Longo A, Coluccia S, Gilli G. Endocrine disrupting activity in fruits and vegetables evaluated with the E-screen assay in relation to pesticide residues. J Steroid Biochem Mol Biol. 2011;127:139-46.

19. Zingue S, Magne Nde CB, Clyne C, Njamen D. Elucidation of underlying mechanisms by which Millettia macrophylla Benth induces its estrogenic activity. ISRN. 2014;2014:8.

20. Zingue S, Tchoumtchoua J, Ntsa DM, Sandjo LP, Cisilotto J, Magne Nde CB, Winter E, Awounfack CF, Ndinteh DT, Clyne C, Njamen D, Halabalaki M, Creczynski-Pasa TB. Estrogenic and cytotoxic potentials of compounds isolated from Millettia Macrophylla Benth. (Fabaceae): towards a better understanding of its underlying mechanisms. BMC Complement Altern Med. 2016;17:65-82.

21. Dzeufiet DPD, Mengue NYS, Bilanda DC, Kameni M, Aboubakar OB-F, Dimo T, Kamtchouing P. In vivo estrogenic-like activities of Gouania Longipetala Hemsl. (Rhamnaceae) bark extracts in a post-menopause-like model of ovariectomized Wistar rats. J Ethnopharmacol. 2015;168:122-8.

22. Ammar S, Contreras MM, Belguith-Hadrich O, Bouaziz M, Segura-Carretero A. New insights into the qualitative phenolic profile of Ficus carica L. fruits and leaves from Tunisia using ultra-high-performance liquid chromatography coupled to quadrupole-time-of-flight mass spectrometry and their antioxidant activity. RSC Adv. 2015:5:20035-50.

23. Soto AM, Lin TM, Justicia H, Silvia RM, Sonnenschein C. Colborn T and Clement C. (Eds.) Chemically induced alterations in sexual development: The wildlife/human connection Princeton 1992. In: An "in culture" bioassay to assess the estrogenicity of xenobiotics. NJ: Princeton Scientific Publishing. p. 295-309.

24. Jiménez-Orozco FA, Rosales AAR, Vega-López A, Domínguez-López ML, García-Mondragón MJ, Maldonado-Espinoza A, Lemini C, Mendoza-Patiño N, Mandoki JJ. Differential effects of esculetin and daphnetin on in vitro cell proliferation and in vivo estrogenicity. Eur J Pharmacol. 2011;668:35-41.

25. Kuiper GG, Carlsson B, Grandien K, Enmark E, Haggblad J, Nilsson S, Gustafsson J-A. Comparison of the ligand binding specificity and transcript tissue distribution of estrogen receptors alpha and beta. Endocrinology. 1997:138:863-70.

26. Deal C. Potential new drug targets for osteoporosis. Nat Clin Pract Rheumatol. 2009:5:20-7.

27. Pitkin J. Alternative and complementary therapies for menopause. Menopause Int. 2012:18:20-7.

28. Silvestini G, Ballanti P, Patacchiioli FR, Mocetti P, Di Grezia R, Wedard BM, Angelucci L, Bonucci E. Evaluation of apoptosis and the glucocorticoid receptor in the cartilage growth plate and metaphyseal bone cells of rats after high dose treatment with corticosterone. Bone. 2000;26:33-42.

29. Baker L, Meldrum KK, Wang M, Sankula R, Vanam R, Raiesdana A, Tsai B, Hile K, Brown JW, Meldrum DR. The role of estrogen in cardiovascular disease. J Surg Res. 2003;115:325-44
30. Parini P, Angelin B, Stavreus-Evers A, Freyschuss B, Eriksson H, Rudling M. Biphasic effects of the natural estrogen 17b-estradiol on hepatic cholesterol metabolism in intact female rats. Arterioscler Thromb Vasc Biol. 2000;20: 1817-23.

31. Ohlsson C, Hellberg N, Parini P, Vidal O, Bohlooly M, Rudling M, Lindberg MK, Warner M, Angelin B, Gustafsson JA. Obesity and disturbed lipoprotein profile in estrogen receptor-alpha-deficient male mice. Biochem Biophys Res Commun. 2000;278:640-5.

32. Saglam K, Polat Z, Yilmaz MI, Gulec M, Akinci SB. Effects of postmenopausal hormone replacement therapy on insulin resistance. Endocrine. 2002;18: 211-4.

33. Fait T, Malkova J, Zivny J. Effect of hormone replacement therapy on the cardiovascular system. Cesk' Gynekol. 2002;67:285-93.

34. Okamura S, Sawada Y, Satoh T, Sakamoto H, Saito Y, Sumino H, Takizawa T, Kogure T, Chaichantipyuth C, Higuchi Y, Ishikawa T, Sakamaki T. Pueraria mirifica phytoestrogens improve dyslipidemia in postmenopausal women probably by activating estrogen receptor subtypes. Tohoku J Exp Med. 2008;216:341-51.

\section{Submit your next manuscript to BioMed Central and we will help you at every step:}

- We accept pre-submission inquiries

- Our selector tool helps you to find the most relevant journal

- We provide round the clock customer support

- Convenient online submission

- Thorough peer review

- Inclusion in PubMed and all major indexing services

- Maximum visibility for your research

Submit your manuscript at www.biomedcentral.com/submit
Biomed Central 